\title{
Understanding and managing worker's exposure to specific risks
}

\author{
Gabriel Bujor Băbuţ, Roland Iosif Moraru, Mihai Popescu-Stelea, and Daniel Nicu Fraitag \\ University of Petrosani, Faculty of Mines, Department of Management and Industrial Engineering, 20 \\ University Street, 332006 Petrosani, Romania
}

\begin{abstract}
The protection of workers exposed to specific risks is regulated by a substantial and well individualized legislation on safety and health at work. Currently there are many difficulties and shortcomings in implementing legal requirements on specific risks assessment and prevention, especially due to their insufficient knowledge and understanding by employers. In this context, starting from detailing and explaining legal requirements applicable, this paper aims to summarize and systematize the information regarding available, both at national and European level, tools and guides prepared for a unitary process of implementation of legal provisions on specific risks assessment and prevention. The paper was structured so as to constitute a legal and methodological guide to assist employers and other interested parties in the effort to implement an efficient and effective management of preventive activities directed to avoid or reduce workers' exposure to specific risks.
\end{abstract}

\section{Introduction}

The national legislation in the field of occupational health and safety is structured in the following categories of normative acts [1]: the general framework; normative acts complementary to the general framework; general health and safety conditions at work; specific activities; specific risks; specific groups; atypical forms of employment; authorizations, approvals and empowerments in the field of occupational safety and health.

A first finding is that despite the fact that the protection of workers exposed to specific risks is devoted to a significant part of the legislation on health and safety at work, the concept of "specific risks" is not defined in a legal sense, and the legislative provisions on this category of risks are relatively few and concise [2-3]. In the normative acts regulating the general framework in the field of occupational safety and health, the following obligations were assigned to the employer regarding the specific risks:

- to achieve and be in possession of an Occupational Health and Safety Risk Assessment for particularly sensitive risk groups (article 12, paragraph 1 (a), in Law no. 319/2006); by the provisions of article 15, paragraph 3 (d), in G.D. no. 1425/2006 was established the obligation to review the Occupational Safety and Health Risk Assessment when a workstation is used by a worker belonging to particularly sensitive risk groups;

${ }^{*}$ Corresponding author: gabriel babut $@$,yahoo.com 
- to protect particularly sensitive risk groups against the hazards that specifically affect them and to set up the workstations taking into account the presence of these groups (articles 35-36 in Law no. 319/2006 and article 67(f) in G.D. no. 1425/2006).

In Annex 6.A of G.D. no. 1425/2006 is stipulated the imposition for the introduction of training in occupational safety and health training programs for employers and workers' representatives with specific responsibilities in the field of workers' health and safety, of the notions of specific risks and of prevention in the sector corresponding to the activity of the enterprise and/or the unit.

The aforementioned issues, plus the poor involvement of the competent authorities and institutions responsible for occupational safety and health in the development and dissemination of tools and guides to assess and prevent workers exposure to specific risks, have led to the current a state that can be characterized as inappropriate [4]. The arguments that support this claim refer to the insufficient knowledge and understanding by employers and other stakeholders of both their legal obligations and the measures they have to adopt and implement in order to fulfil these obligations.

From this perspective, the paper aims to respond to a pressing need existing at national level, a necessity that is directed towards inventorying, systematizing and explaining all legislative regulations aimed at protecting the life, integrity and health of workers against the specific risks that may arise at the workplace and the adoption of the most appropriate measures designed to provide them with physical, mental and social comfort.

\section{Materials and Methods}

The inventory, the systematization and the explanation of all the legal regulations regarding the safety and health protection of the workers against the specific risks was a laborious and difficult but also singular approach, because at the moment there are no specialized papers on the national level that addresses in an integrated and systematic manner this issue, existing only approaches that are limited to a single specific risks category.

In the paper a holistic and systemic approach was used, transposed in a research methodology that consisted of covering the following stages:

- identifying sources of documentation;

- inventory, systematization and explanation of the legal acts that regulate, ensure safety and protect the health of workers exposed to specific risks;

- inventory and systematization of tools and guides available at national and European level to evaluate and prevent exposure of workers to specific risks.

Starting from the fact that the final objective of the theoretical and practical approach proposed in this paper is to establish the constitutive elements of a modern management system of specific risks, the requirements contained in the following standards were considered: ISO 45001 [5], since the determination of legal requirements and other requirements is a clause of this standard; ISO 31000 [6], as specific risk management is an integral part of the global risk management system in an organization.

The sources of documentation used were the following:

- general information:

- the following databases were mainly used: Web of Science - Clarivate Analytics, Scopus and ResearchGate;

- the limited volume of the paper did not allow the mentioning of all the bibliographic sources identified and consulted; in the bibliography of the paper only the most current and the most relevant of them are given, being selected the articles approaching the evaluation of EU legislation concerning risk assessment and preventive measures in safety and health at work [7-10] or the role of employers and 
other interested parties in the improvement of safety and health level at enterprises $[3,11-14]$.

- information on normative acts:

- Ministry of Labour and Social Justice website (section "Legislation"): http://www.mmuncii.ro/j33/index.php/ro/legislatie;

- Labour Inspection website (section "Legislation in the field of safety and health at work"): https://www.inspectiamuncii.ro/86;

- Chamber of Deputies website (section "Legislative repertory"): http://www.cdep.ro/ pls/legis/legis_pck.frame;

- EUR-Lex website (European Union law): https://eur-lex.europa.eu.

- information on the tools and guides available in Romanian at national and European level for assessing and preventing the exposure of workers to specific risks:

- Labour Inspection website (section "Guides"): https://www.inspectiamuncii.ro/ ghiduri;

- National Research and Development Institute of Occupational Safety (INCDPM) "Alexandru Darabont" website (section "Publications/Guides"): http://www.inpm.ro/ ro/oferta-noastra/publicatii/ghiduri.html;

- European Agency for Safety and Health at Work (EU-OSHA) website (section "Tools and publications"): https://osha.europa.eu/ro/tools-and-publications;

- European Commission website (Directorate-General for Employment, Social Affairs and Inclusion, section "Publications and documents"): https://ec.europa.eu/social/.

Since the paper addresses prevailingly the actors involved in ensuring the safety and health at work in Romania, the main criterion that guided the selection of the documentation sources was the linguistic criterion, being retained only sources of documentation that provide documents in Romanian.

As a result, prestigious sources of documentation, represented by international organizations (e.g. International Labor Organization - ILO, World Health Organization WHO, etc.) or national institutions (National Institute for Occupational Safety and Health NIOSH (USA), Health and Safety Executive - HSE (UK), Institut National de Recherche et de Sécurité - INRS (France), Institut de Recherche Robert-Sauvé en Santé et en Sécurité du Travail - IRSST (Canada), etc.), were not mentioned, but their consultation is very strongly recommended to all English/French speakers.

The national and European normative acts mentioned in the paper are not listed as bibliographic references, as this would have led to an excessive and unjustified increase in their number. For the same reason, the bibliographical references were not mentioned in the case of practical tools and guides; only the sources of documentation (web sites from where they can be accessed) are indicated.

\section{Results and discussion}

The specific risks categories were established in accordance with the structure of national legislation used by specialized bodies of the central public administration with competences and responsibilities in the field of occupational safety and health (Ministry of Labour and Social Justice and Labour Inspection). Thus, 12 specific risks categories are mentioned on the Labour Inspection web site. Table 1 lists the applicable national and European legislation for each specific risks category.

The analysis of the data contained in Table 1 allowed highlighting the following aspects:

- with the exception of the specific risk "extreme temperatures", all other specific risks categories are regulated by normative acts transposing the acquis communautaire; 
Table 1. National and European legislation on the protection of workers exposed to specific risks

\begin{tabular}{|c|c|c|c|}
\hline No. & Specific risk & National legislation & $\begin{array}{c}\text { EU legislation } \\
\end{array}$ \\
\hline 1 & Asbestos & $\begin{array}{c}\text { G.D. no. } 1875 / 2005 \\
\text { (amended by G.D. no. 601/2007) }\end{array}$ & $\begin{array}{c}\text { Directive 2009/148/EC } \\
\text { (codification of Directive 83/477/ECC }\end{array}$ \\
\hline 2 & Vibration & $\begin{array}{c}\text { G.D. no. 1876/2005 } \\
\text { (amended by G.D. no. 601/2007) }\end{array}$ & $\begin{array}{c}\text { Directive 2002/44/EC } \\
\text { (amended by Directive 2007/30/EC } \\
\text { and Regulation 1137/2008/EC) }\end{array}$ \\
\hline 3 & Noise & $\begin{array}{c}\text { G.D. no. 493/2006 } \\
\text { (amended by G.D. no. 601/2007) }\end{array}$ & $\begin{array}{c}\text { Directive 2003/10/EC } \\
\text { (amended by Directive 2007/30/EC } \\
\text { and Regulation } 1137 / 2008 / \mathrm{EC} \text { ) }\end{array}$ \\
\hline 4 & $\begin{array}{l}\text { Manual handling } \\
\text { of loads }\end{array}$ & G.D. no. $1051 / 2006$ & $\begin{array}{c}\text { Directive 90/269/EEC } \\
\text { (amended by Directive 2007/30/EC) }\end{array}$ \\
\hline 5 & $\begin{array}{c}\text { Explosive } \\
\text { atmospheres }\end{array}$ & G.D. no. $1058 / 2006$ & $\begin{array}{c}\text { Directive 1999/92/EC } \\
\text { (amended by Directive 2007/30/EC) }\end{array}$ \\
\hline 6 & Biological agents & G.D. no. $1092 / 2006$ & Directive 2000/54/EC \\
\hline 7 & $\begin{array}{l}\text { Carcinogens or } \\
\text { mutagens agents }\end{array}$ & $\begin{array}{l}\text { G.D. no. 1093/2006 } \\
\text { (amended by G.D. no. 1/2012 and } \\
\text { G.D. no. 359/2015) }\end{array}$ & $\begin{array}{c}\text { Directive 2004/37/EC } \\
\text { (amended by Directive 2014/27/EU, } \\
\text { Directive 2017/2398/EU and Directive } \\
\text { 2019/130/EU) }\end{array}$ \\
\hline 8 & Chemical agents & $\begin{array}{c}\text { G.D. no. } 1218 / 2006 \\
\text { (amended by G.D. no. 1/2012, } \\
\text { G.D. no. 359/2015 and G.D. no. } \\
\text { 584/2018) }\end{array}$ & $\begin{array}{c}\text { Directive 98/24/EC } \\
\text { (amended by Directive 2007/30/EC } \\
\text { and Directive 2014/27/EU) } \\
\text { Directive 91/322/CEE } \\
\text { (amended by Directive 2006/15/EC } \\
\text { and Directive 2017/164/EU) } \\
\text { Directive 2000/39/EC } \\
\text { (amended by Directive 2006/15/EC, } \\
\text { Directive 2009/161/EU and Directive } \\
\text { 2017/164/EU) } \\
\text { Directive 2006/15/EC }\end{array}$ \\
\hline 9 & $\begin{array}{l}\text { Artificial optical } \\
\text { radiation }\end{array}$ & G.D. no. $510 / 2010$ & $\begin{array}{c}\text { Directive 2006/25/EC } \\
\text { (amended by Directive 2007/30/EC, } \\
\text { Regulation 1137/2008/EC and } \\
\text { Directive 2013/64/EU) } \\
\end{array}$ \\
\hline 10 & $\begin{array}{l}\text { Sharp [injuries in } \\
\text { the hospital and } \\
\text { healthcare sector] }\end{array}$ & G.D. no. $243 / 2013$ & Directive 2010/32/EU \\
\hline 11 & $\begin{array}{l}\text { Electromagnetic } \\
\text { fields }\end{array}$ & G.D. no. $520 / 2016$ & Directive 2013/35/EU \\
\hline 12 & $\begin{array}{l}\text { Extreme } \\
\text { temperatures }\end{array}$ & $\begin{array}{c}\text { E.O.G. no. 99/2000 } \\
\text { (approved by Law no. } 436 / 2001 \text { ) } \\
\text { G.D. no. 580/2000 }\end{array}$ & - \\
\hline
\end{tabular}

Note: G.D. - Government Decision; E.O.G. - Emergency Ordinance of the Government.

- most of the specific risks are governed by Government Decisions transposing directives derived from the Framework Directive 89/391/EEC (items 2 - 9 and 11), except for the specific risk "asbestos" (governed by a Government Decision transposing a Directive derived from Directive 80/1107/EEC) and for the specific risk "sharp" (regulated by the Government Decision transposing the Directive 2010/32/EU implementing the Framework Agreement on prevention from sharp injuries in the hospital and healthcare sector concluded by HOSPEEM and EPSU);

- the 12 specific risks categories are generated by exposure to physical risk factors (items $2-3,9,11-12$ ), chemical risk factors (items 1, 5, 7 - 8), biological risk factors (item 6), combined risk factors (mechanical - biological) (item 10) or by physical overload (item 
4); with regard to the framing the risk factors on the four components of the work system, with the exception of the physical overload (item 4) falling within the work task, the other risk factors may be classified either in means of production/work equipment or in work environment, depending on the context.

Difficulties and shortcomings in the practical implementation of legal requirements to assess and prevent specific risks are largely due to their insufficient knowledge and understanding by employers. As a logical consequence, in order to facilitate the knowledge and understanding of the concrete way of practical application of the legal requirements for ensuring safety and protecting the health of workers against specific risks, in Table 2 were inventoried, systematized and deployed in a synoptic, clear and concise form, all the legal obligations of employers and other interested parties in this area.

Table 2. Employers' obligations to protect workers exposed to specific risks

\begin{tabular}{|c|c|c|c|c|c|c|c|c|c|c|c|}
\hline $\begin{array}{c}\text { Legal } \\
\text { requirement }\end{array}$ & 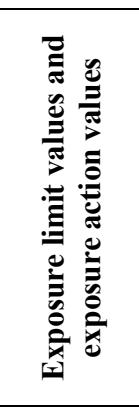 & 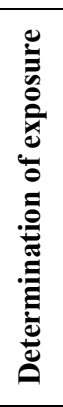 & 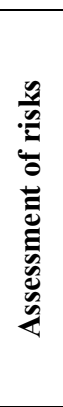 & $\begin{array}{l}0 \\
0\end{array}$ & 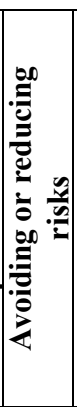 & 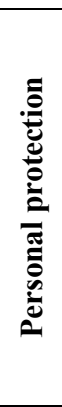 & 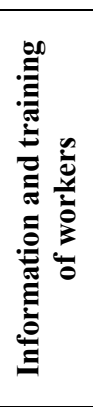 & 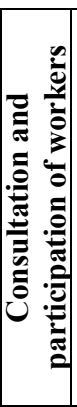 & 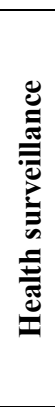 & 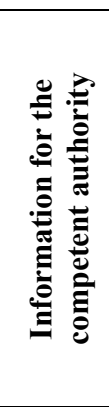 & 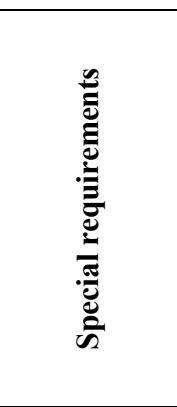 \\
\hline 0 & 1 & 2 & 3 & 4 & 5 & 6 & 7 & 8 & 9 & 10 & 11 \\
\hline Asbestos & $\begin{array}{c}\mathrm{X}^{1} \\
\text { (Exposu- } \\
\text { re limit } \\
\text { values) }\end{array}$ & $\mathrm{X}^{2}$ & $\mathrm{X}^{1}$ & $X^{1}$ & $X^{1}$ & $\mathrm{X}^{2}$ & $\mathrm{X}^{1,2}$ & $\mathrm{X}^{2}$ & $\mathrm{X}^{1}$ & $\begin{array}{c}\mathrm{X}^{1} \\
\text { (Notifi- } \\
\text { cation) }\end{array}$ & Plan of work \\
\hline Vibration & $\mathrm{X}^{1}$ & $\mathrm{X}^{2}$ & $\mathrm{X}^{1}$ & $\mathrm{X}^{1}$ & $\mathrm{X}^{2}$ & $X^{2}$ & $\mathrm{X}^{1}$ & $\mathrm{X}^{1}$ & $\mathrm{X}^{1}$ & - & - \\
\hline Noise & $X^{1}$ & - & $X^{1}$ & $X^{1}$ & $\mathrm{X}^{2}$ & $\mathrm{X}^{1}$ & $\mathrm{X}^{1}$ & $X^{1}$ & $\mathrm{X}^{1}$ & - & - \\
\hline $\begin{array}{c}\text { Manual } \\
\text { handling of } \\
\text { loads }\end{array}$ & - & - & - & $\mathrm{X}^{2}$ & $X^{2}$ & - & $X^{1}$ & $X^{1}$ & $X^{2}$ & - & - \\
\hline $\begin{array}{c}\text { Explosive } \\
\text { atmospheres }\end{array}$ & - & - & $X^{2}$ & - & $X^{2}$ & - & $X^{2}$ & - & - & - & $\begin{array}{c}\text { Explosion } \\
\text { protection } \\
\text { document } \\
\text { Special } \\
\text { require- } \\
\text { ments for } \\
\text { work equip- } \\
\text { ment and } \\
\text { workplaces } \\
\text { Guide of } \\
\text { good } \\
\text { practice }\end{array}$ \\
\hline $\begin{array}{l}\text { Carcinogens or } \\
\text { mutagens } \\
\text { agents }\end{array}$ & $\begin{array}{c}\mathrm{X}^{1} \\
\text { (Exposu- } \\
\text { re limit } \\
\text { values) }\end{array}$ & - & $X^{1}$ & $\mathrm{X}^{1}$ & $X^{1}$ & $\mathrm{X}^{1}$ & $X^{1}$ & $X^{1}$ & $\mathrm{X}^{1}$ & $\begin{array}{c}\mathrm{X}^{1} \\
\text { (Infor- } \\
\text { ma- } \\
\text { tion) }\end{array}$ & $\begin{array}{c}\text { Unforeseen } \\
\text { and } \\
\text { foreseeable } \\
\text { exposure } \\
\text { Access to } \\
\text { risk areas } \\
\text { Hygiene } \\
\text { Guides to } \\
\text { use }\end{array}$ \\
\hline
\end{tabular}




\begin{tabular}{|c|c|c|c|c|c|c|c|c|c|c|c|}
\hline $\mathbf{0}$ & 1 & 2 & 3 & 4 & 5 & 6 & 7 & 8 & 9 & 10 & 11 \\
\hline $\begin{array}{l}\text { Biological } \\
\text { agents }\end{array}$ & - & - & $X^{1}$ & - & $X^{1}$ & $X^{1}$ & $\mathrm{X}^{1}$ & $X^{1}$ & $X^{1}$ & $\begin{array}{c}\mathrm{X}^{1} \\
\text { (Notifi- } \\
\text { cation) }\end{array}$ & $\begin{array}{c}\text { Hygiene } \\
\text { List of } \\
\text { exposed } \\
\text { workers } \\
\text { Health and } \\
\text { veterinary } \\
\text { care } \\
\text { facilities } \\
\text { other than } \\
\text { diagnostic } \\
\text { laboratories } \\
\text { Special } \\
\text { measures for } \\
\text { industrial } \\
\text { processes, } \\
\text { laboratories } \\
\text { and animal } \\
\text { rooms }\end{array}$ \\
\hline $\begin{array}{l}\text { Chemical } \\
\text { agents }\end{array}$ & $\begin{array}{c}\mathrm{X}^{\mathrm{l}} \\
\text { (Occu- } \\
\text { pational } \\
\text { exposu- } \\
\text { re limit } \\
\text { values } \\
\text { and } \\
\text { biologi- } \\
\text { cal limit } \\
\text { values) } \\
\end{array}$ & - & $\mathrm{X}^{1}$ & $X^{2}$ & $\mathrm{X}^{1}$ & $X^{2}$ & $X^{1}$ & $X^{2}$ & $\mathrm{X}^{1}$ & - & $\begin{array}{c}\text { Arrange- } \\
\text { ments to } \\
\text { deal with } \\
\text { accidents, } \\
\text { incidents } \\
\text { and } \\
\text { emergencies } \\
\text { Prohibitions } \\
\text { Guides to } \\
\text { use }\end{array}$ \\
\hline $\begin{array}{c}\text { Artificial } \\
\text { optical } \\
\text { radiation }\end{array}$ & $\begin{array}{c}\mathrm{X}^{1} \\
\text { (Exposu- } \\
\text { re limit } \\
\text { values) }\end{array}$ & $\mathrm{X}^{1}$ & $\mathrm{X}^{1}$ & $\mathrm{X}^{1}$ & - & $\mathrm{X}^{2}$ & $X^{1}$ & $X^{1}$ & $\mathrm{X}^{1}$ & - & $x_{10}$ \\
\hline Sharp & - & - & $X^{1}$ & $X^{2}$ & $X^{2}$ & $X^{2}$ & $X^{1}$ & - & $X^{1}$ & $\begin{array}{c}\mathrm{X}^{1} \\
\text { (Re- } \\
\text { por- } \\
\text { ting) }\end{array}$ & - \\
\hline $\begin{array}{l}\text { Electromagne- } \\
\text { tic fields }\end{array}$ & $\mathrm{X}^{1}$ & $X^{1}$ & $X^{1}$ & - & $X^{1}$ & $X^{2}$ & $X^{1}$ & $X^{1}$ & $\mathrm{X}^{1}$ & $\begin{array}{c}\mathrm{X}^{2} \\
\text { (Infor- } \\
\text { ma- } \\
\text { tion) }\end{array}$ & $\begin{array}{l}\text { Guide of } \\
\text { good } \\
\text { practice }\end{array}$ \\
\hline $\begin{array}{c}\text { Extreme } \\
\text { temperatures }\end{array}$ & $\begin{array}{c}\mathrm{X}^{1} \\
\text { (Exposu- } \\
\text { re action } \\
\text { values) }\end{array}$ & - & - & - & $X^{2}$ & $X^{2}$ & - & - & $\mathrm{X}^{2}$ & - & - \\
\hline
\end{tabular}

The inventory, systematization and explanation of employers' obligations regarding the protection of workers exposed to specific risks were made through a framework structure consisting of 10 categories of legal requirements, to which was added, in order to take into account the requirements applicable to a single specific risk, another category called "special requirements". A legal requirement may be explicitly treated (superscript 1 in Table 2) when it is dedicated to a chapter or section, or by default (superscript 2 in Table 2) when it is found in one or more articles.

Each specific risk is regulated by a variable number of legal requirements, their weight ranging between 30\% (for "explosive atmospheres") and 100\% (for "asbestos"). The share 
of each of the 10 legal requirements in the structure of the 12 legal acts regulating the protection of workers exposed to specific risks varies between 33,33\% (for "information for the competent authority") and 91,66\% (for "avoiding or reducing risks" and "information and training of workers").

The development of good practice tools and guides is both a legal obligation (see Table 2) and a practical necessity imposed by the unitary approach to the application of legal provisions on specific risk assessment and prevention. Table 3 summarizes the Romanianlanguage guides available at national and European level for assessing and preventing the exposure of workers to specific risks. Although the EU-OSHA website provides numerous and varied tools and publications designed inclusively for specific risks, none of them fall into the European Guides category and, as a result, this source of documentation has not been retained in Table 3. The limited volume of the paper did not allow the detailed inventory of guides to be presented, with only the availability (X / -) and their number being indicated for each document source. Detailed information may be requested by the authors of the paper for all interested parties.

Table 3. Guides available online to evaluate and prevent the exposure of workers to specific risks

\begin{tabular}{|c|c|c|c|}
\hline Specific risk & Labour Inspection & INCDPM & $\begin{array}{c}\text { European } \\
\text { Commission }\end{array}$ \\
\hline Asbestos & $\mathrm{X}\left(1^{1}\right)$ & $\mathrm{X}\left(1^{1}\right)$ & $\mathrm{X}\left(4^{1,4}\right)$ \\
\hline Vibration & - & $\mathrm{X}\left(1^{1}\right)$ & $\mathrm{X}\left(1^{1}\right)$ \\
\hline Noise & - & $\mathrm{X}\left(1^{1}\right)$ & $\mathrm{X}\left(1^{1}\right)$ \\
\hline Manual handling of loads & - & $\mathrm{X}\left(1^{1}\right)$ & $\mathrm{X}\left(5^{1,4}\right)$ \\
\hline Explosive atmospheres & - & - & $\mathrm{X}\left(1^{1}\right)$ \\
\hline Biological agents & $\mathrm{X}\left(1^{2}\right)$ & $\mathrm{X}\left(1^{1}\right)$ & $\mathrm{X}\left(1^{1,3}\right)$ \\
\hline Carcinogens or mutagens agents & $\mathrm{X}\left(1^{1}\right)$ & $\mathrm{X}\left(1^{1}\right)$ & - \\
\hline Chemical agents & $\mathrm{X}\left(2^{1}\right)$ & $\mathrm{X}\left(2^{1}\right)$ & $\mathrm{X}\left(1^{1}\right)$ \\
\hline Artificial optical radiation & - & - & $\mathrm{X}\left(1^{1}\right)$ \\
\hline Sharp & - & - & $\mathrm{X}\left(3^{1}\right)$ \\
\hline Electromagnetic fields & - & - & $\mathrm{X}\left(1^{1,3}\right)$ \\
\hline Extreme temperatures & - & - & - \\
\hline
\end{tabular}

Note: ${ }^{1}$-online; ${ }^{2}$-paper format; ${ }^{3}$-issue partially treated; ${ }^{4}$-SLIC $=$ Senior Labour Inspectors Committee.

\section{Conclusions}

The protection of workers against specific risks is a particularly important part of the national, European and international legislative framework in the field of health and safety at work and is comprised of a relatively large number of distinct and well individualized regulations.

The difficulties and deficiencies encountered in the process of implementing legal requirements for specific risk assessment and prevention have negatively affected this process, with adverse consequences in terms of ensuring the safety, health and well-being of workers. The analysis of the difficulties and deficiencies found was based on a unitary and systematic approach to the causes that generated them. Thus, they have been structured on two levels: legislative (unclear, outdated or contradictory legal requirements; different structure of normative acts which regulates the different categories of specific risks) and organizational (insufficient knowledge or lack of knowledge by employers, workers and other interested parties of their legal obligations and rights; insufficient information, training, consultation and participation of workers; lack of procedures for assessing and preventing specific risks or their incomplete character and/or not updating them; inefficient 
communication; sporadic or ineffective control of compliance with legal obligations; the poor involvement of the competent authorities and institutions responsible for occupational safety and health in the development and dissemination of tools and guides; absence or ineffective functioning of the health and safety management system).

In order to eliminate and/or diminish the negative impact of the causes generating difficulties and deficiencies in the process of implementation of the legal requirements for assessment and prevention of specific risks, the following issues were addressed in the paper:

- improving the national and European legislative framework in the field of worker protection against specific risks by proposing a single framework structure for all regulatory acts that regulate the different categories of specific risks;

- improving the awareness of employers 'and other stakeholders' legal obligations in the field of worker protection against specific risks by inventorying, systematizing and explaining them in a synoptic, clear and concise form;

- facilitating the implementation of effective management of preventive activities by inventorying and systematizing the tools and guides available at national and European level to assess and prevent exposure of workers to specific risks.

This paper is part of a series of articles aiming to contribute to the knowledge and to the correct and uniform application of the legal requirements in the field of occupational safety and health by inventorying, systematizing and explaining them. As a result, considering that physical and mental integrity of workers is related to the adequate information and conditions of occupational health and safety workplace and their right to quality work, this paper is a legislative and methodological guide for facilitating cooperation between employers and workers and their respective organizations with a view to eliminating or minimizing work-related specific risks.

\section{References}

1. G.B. Băbuţ, R.I. Moraru, Proceedings of the 16th International Multidisciplinary Scientific GeoConference SGEM 2016 2, 635-642 (2016)

2. G.B. Băbuţ, R.I. Moraru, Quality - Access to Success 19(166), 133-144 (2018)

3. Evaluation of the EU Occupational Safety and Health Directives - Country summary report for Romania. Available on https://ec.europa.eu/social/BlobServlet?docId=17123\&langId=en

4. R.I. Moraru, G.B. Băbuț, L.I. Cioca, Proceedings of the 5th International Conference on Manufacturing Science and Educations MSE 2011 2, 363-366 (2011).

5. D.C. Darabont, C. Bejinariu, I. Ionita, M.A. Bernevig-Sava, C. Baciu, E.R. Baciu, Environ Eng Manag J 17(11), 2711-2718 (2018)

6. R.I. Moraru, G.B. Băbuț, Quality - Access to Success 11(4), pp. 50-59 (2010)

7. J.H. Andersen, P. Malmros, N.E. Ebbehoej, E.M. Flachs, E. Bengtsen, J.P. Bonde, Scand J Work Environ Health 45(2), 103-113 (2019)

8. E. MacEachen, A. Kosny, C. Ståhl, F. O'Hagan, L. Redgrift, S. Sanford, C. Carrasco, E. Tompa, Q. Mahood, Scand J Work Environ Health 42(1), 3-16 (2016)

9. T. Niskanen, P. Naumanen, M.L. Hirvonen, Appl Ergon 43(5), 829-842 (2012)

10. E. Tompa, C. Kalcevich, M. Foley, C. McLeod, S. Hogg-Johnson, K. Cullen, E. MacEachen, Q. Mahood, E. Irvin, Am J Ind Med 59(11), 919-933 (2016)

11. G. Hrenov, K. Reinhold, M. Tint, P. Tint, Proceedings of the 28th International European Safety and Reliability Conference ESREL 2018, 2879-2888 (2018)

12. L. Ivascu, L.I. Cioca, Safety 5(1), 12 (2019)

13. R.I. Moraru, G.B. Băbuţ, M. Popescu-Stelea, Quality - Access to Success 15(139), 104-108 (2014)

14. D. Păsculescu, L. Pană, V.M. Păsculescu, F. Deliu, Mining of Mineral Deposits 13(2), 1-16 (2019) 